\title{
EFFECTS OF ATHLETIC TAPING ON PERFORMANCE OF BASKETBALL ATHLETES WITH CHRONIC ANKLE INSTABILITY
}

\author{
EFEITOS DA FITA ATLÉTICA NA PERFORMANCE DE ATLETAS DE BASQUETE COM INSTABILIDADE \\ CRÔNICA DETORNOZELO
}

\author{
EFECTOS DE LA CINTA ATLÉTICA EN EL DESEMPEÑO DE LOS ATLETAS DE BALONCESTO CON \\ INESTABILIDADCRÓNICADETOBILLO
}

\section{Luiza Cammerer Gehrke1 (Physiotherapist) \\ Leonardo Ximenes Londero' (Physical Educator) \\ Renata Fanfa Loureiro-Chaves ${ }^{1}$ (Physiotherapist) \\ Henrique Hahn Souza' \\ (Physiotherapist) \\ Gabriel Pizetta de Freitas ${ }^{1}$ \\ (Physiotherapist) \\ Adriana Moré Pacheco \\ (Physiotherapist) \\ 1. Universidade Federal do Rio Grande do Sul, Porto Alegre, RS, Brazil.}

\section{Correspondence: \\ Adriana Moré Pacheco. \\ Escola de Educação Física, \\ Fisioterapia e Dança. Universidade Federal do Rio Grande do Sul. Rua: Felizardo, 750, Porto Alegre, \\ RS, Brazil. 90690-200. \\ adrimpacheco@ufrgs.br}

\begin{abstract}
Introduction: Ankle sprains are recurrent injuries in basketball, hence more and more athletes are taping their ankles to promote joint stability, aiming at improving dynamic balance and, consequently, functional performance. Objective: To verify the effects of elastic and rigid athletic taping on the functional performance and level of comfort of basketball players with chronic ankle instability. Methods: Twenty-one athletes aged between 18 and 30 years (mean age $23.7 \pm 3.2$ ) with chronic ankle instability (CAI), verified using the Cumberland Ankle Instability Tool, were selected to take part in this study. The Star Excursion Balance Test (SEBT) and the Figure-of-8 hop test (F8) were applied unilaterally to assess functional performance, considering the ankle of greater instability in three situations: without athletic taping, with rigid athletic taping and with elastic athletic taping. A draw was held to determine the order in which the tests (held over a number of days) would be applied. A questionnaire was conducted to assess comfort on the same day the athletic tapes were applied. Results: There was no significant difference between the tests in any direction of the SEBT, but there was a significant difference in $F 8$ between the rigid athletic taping $x$ control and elastic athletic taping $x$ control situations. In addition, the elastic athletic tape was considered significantly more comfortable than the rigid athletic tape. Conclusion: Athletic taping appears to effectively improve the dynamic balance and functional performance of athletes with CAI only in activities that cause considerable joint stress, as is the case in F8. Elastic athletic tape appears to be just as effective as rigid athletic tape in these situations, in addition to being a significantly more comfortable alternative. Levef of Evidence l; High quality randomized trial with statistically significant difference or no statistically significant difference but narrow confidence intervals.
\end{abstract}

Keywords: Athletic performance; Postural balance; Joint instability; Athletic tape; Ankle.

\section{RESUMO}

Introdução: No basquete, as entorses de tornozelo são lesões recorrentes e, por isso, cada vez mais atletas vêm utilizando fitas atléticas para de promover a estabilização articular, visando a melhora do equilibrio dinâmico e, consequentemente, da performance funcional. Objetivo: Verificar os efeitos da fita atlética elástica e rígida sobre a performance funcional e o nível de conforto dos jogadores de basquete que têm instabilidade crônica de tornozelo. Métodos: Foram selecionados para este

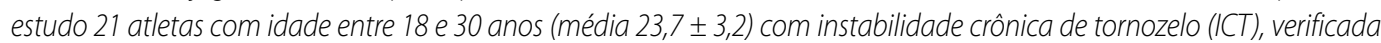
com a Cumberland Ankle Instability Tool. O Star Excursion Balance Test (SEBT) e o Figure-of-8 hop test (F8) foram realizados unilateralmente para avaliar a performance funcional, considerando o tornozelo de maior instabilidade em três situações: sem fita atlética, com fita rígida e com fita elástica. Um sorteio foi realizado para determinar a ordem na qual os testes (mantidos por vários dias) seriam aplicados. Um questionário foi conduzido para avaliar o conforto no mesmo dia em que as fitas atléticas foram aplicadas. Resultados: Não houve diferença significativa entre os testes em nenhuma direção do SEBT, mas houve diferença significativa no F8 entre as tiras atléticas rígida vs. controle e elástica vs. controle. Além disso, a fita atlética elástica foi considerada significativamente mais confortável do que a rígida. Conclusão: As fitas atléticas parecem melhorar efetivamente o equilibrio dinâmico e a performance funcional de atletas com ICT apenas em atividades que ocasionam grande estresse articular, como o F8. A fita atlética elástica parece ser uma alternativa tão eficaz quanto a rígida nessas situações, além de ser uma alternativa significativamente mais confortável. Nível de Evidência l; Estudo clínico randomizado de alta qualidade com ou sem diferença estatisticamente significante, mas com intervalos de confiança estreitos.

Descritores: Desempenho atlético; Equilibrio postural; Instabilidade articular; Fita atlética; Tornozelo.

\section{RESUMEN}

Introducción: En el baloncesto, los esguinces de tobillo son lesiones recurrentes y debido a esto, cada vez más atletas han utilizado cintas atléticas con el fin de promover estabilidad articular, con el objetivo de mejorar el equilibrio dinámico y en consecuencia el rendimiento funcional. Objetivo: Verificar los efectos de la cinta atlética elástica y rígida sobre el rendimiento funcional y nivel de comodidad de los jugadores de baloncesto que tienen inestabilidad crónica de tobillo. Métodos: Fueron seleccionados para este estudio 21 atletas con edad entre 18 y 30 años 
(promedio 23,7 $\pm 3,2$ ) con inestabilidad crónica de tobillo (ICT), verificada con la Cumberland Ankle Instability Tool. Para evaluar el desempeño funcional se realizó el Star Excursion Balance Test (SEBT) y el Figure-of-8 hop (F8) de forma unilateral, teniendo en cuenta el tobillo de mayor inestabilidad en tres situaciones: sin cinta atlética, con cinta rígida y con cinta elástica. Los tests sellevaron a cabo en el orden definido por sorteo, y se realizaron en días diferentes. El mismo día que se utilizaron las cintas atléticas se aplicó un cuestionario para evaluar la comodidad de las cintas atléticas. Resultados: No hubo diferencia significativa entre los tests en ninguna dirección del SEBT, pero hubo diferencia significativa en el F8 entre las cintas atléticas rígidas vs. control y elásticas vs. control. Además, la cinta atlética elástica fue significativamente más cómoda que la rígida. Conclusión: Las cintas atléticas parecen mejorar efectivamente el equilibrio dinámico yel desempeño funcional de atletas con ICT sólo en actividades que causan gran estrés articular, como el F8. La cinta atlética elástica parece ser una alternativa tan eficaz como la rígida en estas situaciones, además de ser significativamente más cómoda. Nivel de Evidencia l; Estudio clínico aleatorio de alta calidad, con o sin diferencia estadísticamente significativa, pero con estrechos intervalos de confianza.

Descriptores: Rendimiento atlético; Balance postural; Inestabilidad de la articulación; Cinta atlética; Tobillo.

\section{INTRODUCTION}

Different types of athletic tape have been used in the prevention of sports injuries promoting protection and support for the joint or muscles during movement ${ }^{1}$. The most commonly used type of taping is rigid ${ }^{1}$, which provides stability enhancement through the limitation and deceleration of joint movements, as well as afferent impulses to the central nervous system, improving the joint position and direction of motion ${ }^{2,3}$. Since the 2008 Olympic Games, however, another type of athletic tape has become increasingly popular among athletes and in clinical practice ${ }^{4}$.

The elastic tape, specifically the KinesioTaping ${ }^{\circledR}$ brand (KT), was developed in Japan in the year 1970 by the chiropractor Kenso Kase ${ }^{4}$. Unlike rigid tape, it has elasticity, allowing a greater range of motion, and it can be elongated up to $140 \%$ of its longitudinal length before application, promoting a constant friction force on the skin ${ }^{1,4,5}$. Such friction force contributes to the improvement of kinaesthetic awareness, since the constant pressure and elongation generated by the tape can stimulate mechanoreceptors providing information about movement and articular position 5,6. In addition, KT also promotes correction of joint misalignment and support to muscles and fascia during movement ${ }^{6}$.

Tapes are constantly used to reduce the occurrence of injuries in multidirectional sports, functioning as external support and providing stability through mechanisms such as limiting movement and improving kinesthesis, by the increase of proprioceptive stimuli on the skin ${ }^{3,7}$. They are mainly used for athletes who have had ankle sprains, which is the most recurrent among the sports injuries ${ }^{3,8,9}$, occurring generally in modalities with physical contact ${ }^{8,10}$ and with high jump frequency, such as volleyball or basketball8.

Ankle sprains commonly lead to the development of chronic ankle instability (CAI), which is characterized by recurrent sprains ${ }^{11,12}$, with damaged ligaments and tendons and, mainly, damaged joint mechanoreceptors. This clinical case leads to reduced proprioception and neuromuscular control, as well as deficits in strength and functional performance ${ }^{3,13,14}$.

Thus, considering the stabilizing action of the tapes, according to Hettle et al. ${ }^{13}$, it is speculated that its use can promote an increase of the dynamic balance. However, there are differences in the literature regarding their effect in functionality ${ }^{9,13}$.

According to Günay, Karaduman, and Öztürk, ${ }^{14}$ a good external implement is one that promotes restriction of ankle movement and increase of joint stability without compromising functional performance. However, there is no consensus regarding the effects of $K T$ in these aspects. Hence, it is extremely important that more studies verify if these implements promote greater stability and, if so, which would be the most appropriate. It is also important to take into account the range of motion restriction, comfort and functionality of the athletes. Therefore, the objective of this study was to verify the effects of elastic and rigid tapes on the functional performance and level of comfort in basketball athletes who have chronic ankle instability.

\section{METHODOLOGY}

The sample calculation was performed using the Santos, Abbud and Abreu formula ${ }^{15}$ to determine the sample size (n) based on the population estimate, which is finite and known. Considering that the validity and reliability of the SEBT to detect functional performance deficits in individuals with CAl is quite discussed in the literature, ${ }^{16}$ and that this is a widely used test ${ }^{9,10,13}$, the calculation was based on the Figure-of- 8 hop test by Docherty et al. ${ }^{17}$, considering the results of athletes with mild degrees of instability. For a level of significance of 5\%, a standard deviation of 1.2617 and a mean of 7.18 seconds ${ }^{17}$ will require at least 20 athletes, however, taking into account a possible sample loss of 5\%, the sample was composed by 21 athletes.

The research was carried out in a quantitative cross-sectional randomized trial ${ }^{18}$ composed by 21 athletes of the female and male basketball teams of the Federal University of Rio Grande do Sul, with ages ranging from 18 to 30 years (mean $23.7 \pm 3.2$ ). The athletes had been practicing the modality for at least one year, had a training frequency of at least once a week, and met the criteria developed by the International Consortium of the Ankle ${ }^{12}$, which is a community of researchers and clinicians seeking disseminate knowledge through research related to joint pathologies ${ }^{12}$. The Consortium defends inclusion and exclusion criteria for patient participation in studies in order to improve quality and increase validity of research developed with CAl, since this is a complex and multifactorial condition ${ }^{12}$. Thus, athletes meeting certain criteria had episodes of subjective sensation of instability in the last six months and obtained a score of less than or equal to 24 in the Cumberland Ankle Instability Tool (CAIT), which is a questionnaire developed to analyse stable ankles and assess the severity of functional joint instability ${ }^{19}$. The athletes also had to meet the exclusion criteria of the International Ankle Consortium ${ }^{12}$, which are: no history of surgery in musculoskeletal structures of the lower limbs and no injury of the lower limbs in the past three months.

As soon as they agreed to participate in the research, the athletes signed the free and informed consent form approved by the Research Ethics Committee of the university, on March 10th of 2016, under the number CAAE 52630416.8.0000.5347, in accordance with Resolution $466 / 2012$ of the National Health Council.

\section{Data Collection Procedures}

Initially, the athletes answered individually to two instruments: an anamnesis form in order to characterize the sample and to verify 
compliance with the inclusion and exclusion criteria of the study, and the CAIT, which is structured in nine items and generates a score between zero and 30 for each ankle, where zero means severe instability, and 30 means normal stability ${ }^{19}$. The ankle presenting the greatest instability, according to the questionnaire, was evaluated in the study.

After this first step, each of the selected athletes performed a simple draw to verify the order ( $A, B$ or $C$ ) of the study situations: $A$ ) without any ankle stabilizer implement (control group), B) with rigid tape, and C) with elastic tape. Each situation was evaluated on a different day, with a minimum interval of 24 hours and maximum of one week, totalling three distinct days of data collection with each athlete. The athletes used the same socks and sneakers they used for training, which made the proprioceptive stimulus generated by these materials always the same in all study situations. The use of sneakers occurred so that it was possible to approach the functional tests of the sport practice and to avoid accidents such as slipping.

On each day of collection, from each of the study situations, the athletes performed a warm-up (running on a treadmill at a speed chosen by the athlete for five minutes), received the taping application or not, depending on the situation, and finally were evaluated for functional performance through the Star Excursion Balance Test (SEBT) and the Figure-of-8 hop test.

The SEBT consisted of a series of mini unilateral squats performed in the centre of a wind rose. The subject attempted to reach as far as possible in each of the eight directions with the opposite leg, according to the protocol used by Peres et al. It is considered that the greater the distance reached in the test, the better the functional performance of the subject ${ }^{20}$ and the greater the ankle stability. There is a relation between the distance, the demand on the balance and neuromuscular control systems ${ }^{10,21}$. For the SEBT, a panel from the study of Peres et al. ${ }^{10}$ was positioned on the ground (Figure 1). On each day, the test was preceded by a familiarization and then performed three times, with an average of centimetres being recorded for each of the eight directions. The athletes performed the test with their hands at the waist, kept the support foot completely on the ground during the execution (Figure 1)

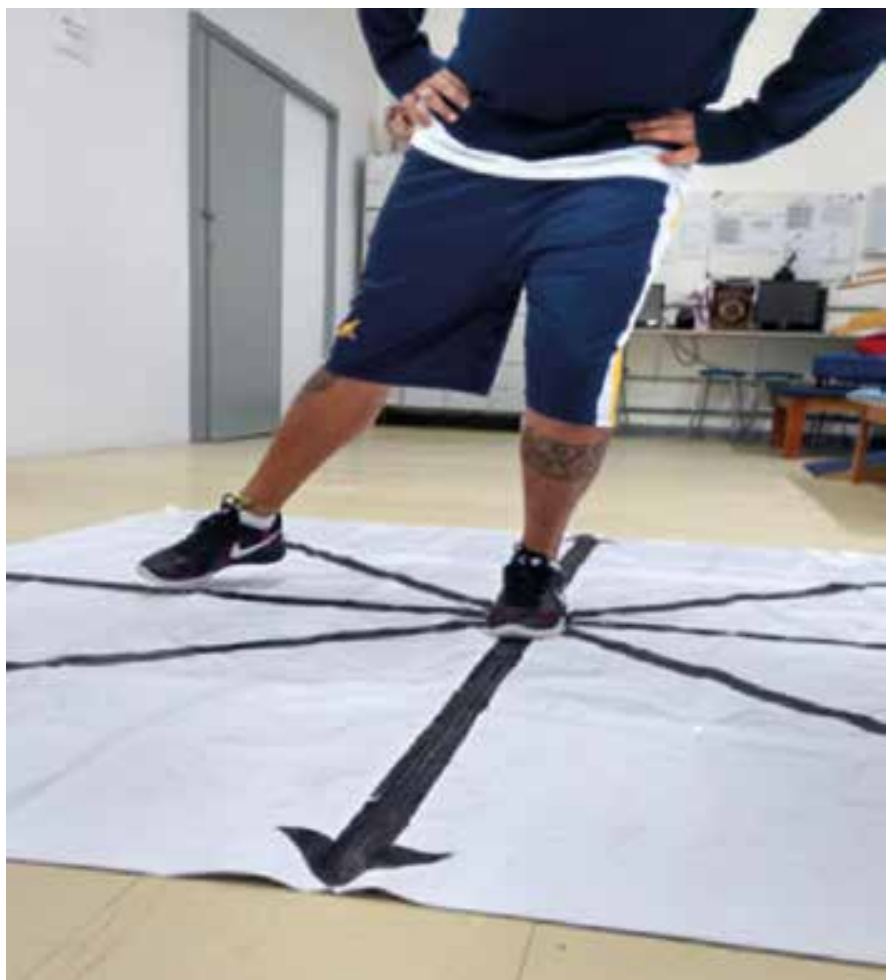

Figure 1. Athlete performing SEBT with the panel from Peres et al., $2014^{21}$. and, between each of the three performances, had a rest time of approximately one and a half minutes or equivalent time to what the athlete indicated necessary to retake the test without losing the fatigue.

After the SEBT, each athlete performed the Figure-of-8 hop test (F8) when considered fit. F8 is an agility test involving unipedal jumps combined with abrupt changes of direction ${ }^{17,22}$ and it encompasses several physical components such as coordination and speed, and is, therefore, a good representation of the functional movements required during sports practice 22 . For the test, a course of two cones separated by five meters with another cone marking the half of the route in a straight line (Figure 2) was positioned. Each athlete was instructed to perform the course in order to draw an " 8 " two consecutive times, jumping on one leg only as fast as possible (Figure 2). On each day, the test was preceded by a familiarization and performed three times with one minute of rest between each one, as in the study by Caffrey et $\mathrm{al}^{22}$. The shortest time between the three trials was chosen for the statistical analysis, as in the study of Dochertyet al. ${ }^{17}$, because the shorter the time of accomplishment of the course, the better functional performance of the athlete ${ }^{17}$.

On the days involving performance evaluation in situations of rigid or elastic tape, athletes responded the Modified Schechter Scale for Comfort Level Assessment after the tests in order to verify comfort regarding the tapes. The results are scaled from zero to ten; zero being no comfort and ten being the sensation of maximum comfort ${ }^{23}$.

The elastic tape used in the study was from the brand dlKintape ${ }^{\circledR}$ (2011, Jiangsu, China) and its application was based on the study of Kuni et al. ${ }^{24}$ With the ankle in neutral position, the midpoint of a tape was applied to the plantar region of the hind foot so that two halves were left, one medial and one lateral to the ankle. The medial half was applied with $100 \%$ of tension towards the internal malleolus, being finished just above it. The lateral half was applied in the same way, however, towards the lateral region of the leg, ending at the same height of the medial part of the tape (Figure 3). A second tape was also applied from its midpoint, located between the hind foot and mid foot. The medial part was applied with 100\% tension in the upper and lateral direction, passing through the anterior region of the joint and reaching the distal posterior side of the leg. The other part of the tape, the lateral one, was applied with the same tension, however, in an upper and medial direction, crossing the first half in the anterior region of the joint and reaching the distal posterior medial portion of the leg (Figure 3).

The rigid tape from the brand Cremer $^{\circledR}$ (1935, Santa Catarina, Brazil), of size $2.5 \mathrm{~cm} \times 4.5 \mathrm{~m}$, was used for the application. The application was based on the studies of Kuni et al. ${ }^{24}$ and Wilkerson ${ }^{2}$, so that, also in an ankle neutral position, two anchors were placed - one above the malleolus and the other in the middle region of the metatarsals - following the application of three longitudinal ribbons from the medial region to the lateral one passing through the hind foot (Figure 4-A),

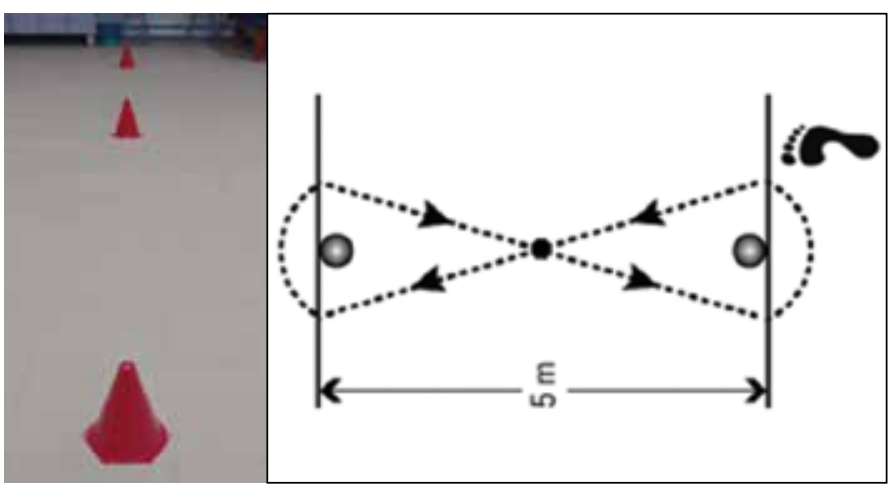

Figure 2. Figure-of-8 hop test used in the present study (left) with example (right) by Caffrey et al. ${ }^{22}$ 
three horseshoe-shaped horizontal ribbons with a midpoint in the Achilles tendon and with the tips at the distal anchor (Figure 4-B), a tape for stabilization of the subtalar joint that leaves the lateral dorsal region, crosses the diagonal region of the plantar, and then the anterior region of the joint is terminated in the lateral malleolus (Figure 4-C) and, finally, anchor ribbons Figure 4-D).

Both applications of tapes were preceded by shaving and hygienization of the skin with alcohol ethyl 70\% hydrated. The elastic tape had its ends rounded before application. The study collection stages were performed by two different evaluators: one trained for the placement of the tapes and the other a blind evaluator.

\section{Statistical analysis}

Quantitative variables were described by mean and standard deviation and qualitative variables by absolute and relative frequencies. To compare the three study situations, Analysis of Variance (ANOVA) for repeated measures complemented by the Least Significance Difference (LSD) test was performed. In the comparison of comfort between the situations with tape, the t-student test for paired samples was used. The significance level adopted was $5 \%(p<0.05)$ and the analysis were performed in the SPSS version 21.0 program (University of Chicago, USA).

\section{RESULTS}

Twenty-two athletes from basketball teams met the inclusion criteria of the study, however, there was a sample loss of one athlete due to injury, therefore, twenty-one athletes (7 women and 14 men, mean age of 23.7 years \pm 3.2 , and $\mathrm{BMI}$ of $23.8 \pm 2.3$ ) were part of the study. Of these, 13 had a sprain in the last year and 16 claim to use ankle protection during sports, of which only five always use it.
The most commonly used protections are elastic ankle braces with and without metallic stabilizers (13 athletes), but most of the athletes (15) had already used rigid tape. No athlete was sensitive to the material of the tapes, nor interrupted the performance of the functional tests. Regarding the CAIT questionnaire, the mean scores were $17.8 \pm 5.4$ and the ankle with the greatest instability, which was consequently evaluated in the functional tests, was the left in 15 athletes and the right in 6 (Table 1 ).

After performing the functional tests, it was verified that there was no significant difference between the three situations of the study in any of the eight directions of the SEBT. In the majority of these, the control situation (without tape) presented worse results (lower averages) and tape situations presented the best results (highest averages). In the Figure-of-8 hop test, there was a significant difference ( $p=0.049)$ only between the conditions of rigid tape compared to control and elastic tape compared to control, being this difference favourable to situations involving the use of tape. Finally, in relation to the comfort of the implements, the elastic tape was significantly $(p<0.001)$ more comfortable than the rigid tape (Table 2).

\section{DISCUSSION}

This study aimed to verify the effects of rigid and elastic tapes on the functional performance and comfort level of basketball athletes with chronic ankle instability.

According to Silva and Gonçalves, ${ }^{25}$ the use of tape and other ankle support reduces the severity and incidence of sprains in $60-80 \%$ of cases, especially in individuals who have already suffered the injury. These implements are indicated as a prophylactic measure, mainly for athletes who are frequently exposed to situations of jumping, lateral displacement and running. Such practice is common in basketball

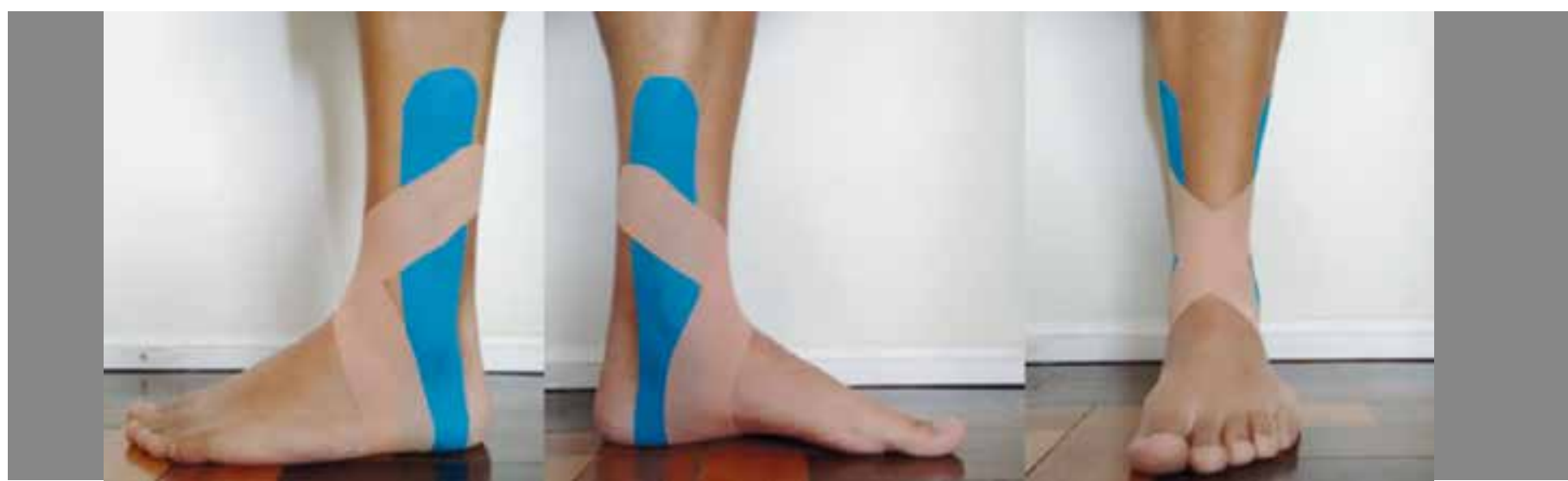

Figure 3. Elastic tape positioning with a blue and bege tape.

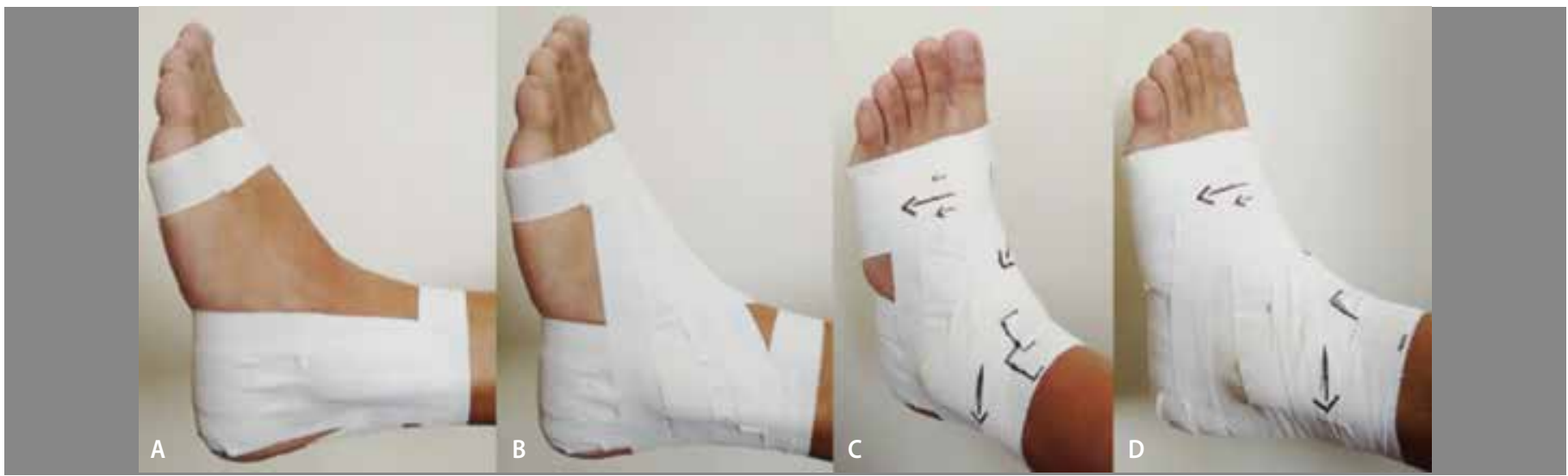

Figure 4. Every step of the rigid tape application. 
Table 1. Sample characterization.

\begin{tabular}{|c|c|}
\hline Variables & $n=21$ \\
\hline \multicolumn{2}{|l|}{ Sex } \\
\hline Female & $7(33,3)$ \\
\hline Male & $14(66,7)$ \\
\hline Age (years) - mean \pm SD & $23,7 \pm 3,2$ \\
\hline $\mathrm{BMI}\left(\mathrm{kg} / \mathrm{m}^{2}\right)-$ mean $\pm \mathrm{SD}$ & $23,8 \pm 2,3$ \\
\hline \multicolumn{2}{|l|}{ Use of Bracing to Play - n (\%) } \\
\hline Yes & $16(76,2)$ \\
\hline No & $5(23,8)$ \\
\hline \multicolumn{2}{|l|}{ Use of Bracing Frequency - n (\%) } \\
\hline Always & $5(31,25)$ \\
\hline In case of fear of injury or pain & $11(68,75)$ \\
\hline \multicolumn{2}{|l|}{ Type of Bracing - $\mathrm{n}(\%)$} \\
\hline Elastic Brace with or without metal & $13(81,25)$ \\
\hline \multicolumn{2}{|l|}{ stabilizer } \\
\hline Elastic Tape & $1(6,25)$ \\
\hline Bandage & $2(12,50)$ \\
\hline \multicolumn{2}{|l|}{ Previous use of tape- $n(\%)$} \\
\hline Rigid & $15(88,23)$ \\
\hline Elastic & $2(11,77)$ \\
\hline \multicolumn{2}{|l|}{ Ankle Sprain in previous year - $\mathrm{n}(\%)$} \\
\hline Yes & $13(61,9)$ \\
\hline No & $8(38,1)$ \\
\hline \multicolumn{2}{|l|}{ Unstable Ankle (CAIT) - n (\%) } \\
\hline Right & $6(28,6)$ \\
\hline Left & $15(71,4)$ \\
\hline CAIT Score - mean \pm SD & $17,8 \pm 5,4$ \\
\hline
\end{tabular}

Table 2. Comparison between 3 study conditions, in each direction in SEBT, Figure-of-8 hop test and comfort

\begin{tabular}{c|c|c|c|c}
\hline Variable & Control & Rigid Tape & Elastic Tape & $p$ \\
\hline & Mean \pm SD & Mean \pm SD & Mean \pm SD & \\
\hline SEBT A $(\mathrm{cm})$ & $71,8 \pm 6,5$ & $70,8 \pm 6,1$ & $72,7 \pm 6,1$ & 0,181 \\
\hline SEBT AM $(\mathrm{cm})$ & $76,6 \pm 6,5$ & $76,3 \pm 6,5$ & $78,4 \pm 6,6$ & 0,111 \\
\hline SEBT M $(\mathrm{cm})$ & $79,9 \pm 9,6$ & $80,6 \pm 9,8$ & $81,7 \pm 7,4$ & 0,516 \\
\hline SEBT PM $(\mathrm{cm})$ & $83,9 \pm 12,0$ & $85,2 \pm 10,4$ & $86,3 \pm 9,2$ & 0,477 \\
\hline SEBT P $(\mathrm{cm})$ & $85,1 \pm 15,0$ & $86,4 \pm 13,8$ & $87,8 \pm 11,2$ & 0,464 \\
\hline SEBT PL $(\mathrm{cm})$ & $76,1 \pm 14,4$ & $78,0 \pm 13,4$ & $79,6 \pm 12,0$ & 0,409 \\
\hline SEBT L $(\mathrm{cm})$ & $63,1 \pm 14,2$ & $63,4 \pm 12,3$ & $66,2 \pm 13,0$ & 0,154 \\
\hline SEBT AL $(\mathrm{cm})$ & $60,8 \pm 5,8$ & $61,3 \pm 5,6$ & $61,2 \pm 5,7$ & 0,814 \\
\hline Figure-of-8 $(\mathrm{s})$ & $10,8 \pm 1,8^{b}$ & $10,3 \pm 1,5^{\mathrm{a}}$ & $10,3 \pm 1,5^{\mathrm{a}}$ & 0,049 \\
\hline Comfort & - & $5,38 \pm 2,24$ & $8,93 \pm 1,16$ & $<0,001$ \\
\hline
\end{tabular}

a,b Equal letters do not differ for the LSD Test (Least Significance Difference) with a $5 \% ; A=$ anterior, $A M=$ anterio medial, $\mathrm{M}=$ =medial, $\mathrm{PM}=$ posterior medial, $\mathrm{P}=$ posterior, $\mathrm{PL}=$ posterior lateral, $\mathrm{L}=$ lateral, $\mathrm{AL}=$ =anterior lateral.

due to the proprioceptive and mechanical benefits generated and its contribution to joint stability $7,25,26$. Despite the reduction in severity and incidence of sprains resulting from better joint stabilization by the use of external ankle support, the influence of these implements on the functional performance of the individuals is still not clear ${ }^{26,27}$

The Bicici, Karatas and Baltaci ${ }^{9}$ study evaluated the functional performance of basketball athletes in four situations (without tape, placebo, with elastic tape and with rigid tape), through several functional tests, among them the SEBT. The authors, corroborating the findings of this study, found no significant difference for any direction of the SEBT in any of the situations tested, however, unlike this study; the authors did not find a trend of better or worse outcome in any situation. This can be explained by the difference between the tape application methods, especially the elastic kind, and by the mean of CAIT, which was 17.8 in the present study. In the Bicici, Karatas and Baltaci ${ }^{9}$ study it was 22, 53, characterizing a sample with more stable ankles, which, as the literature demonstrates, does not gain in the functional performance in the SEBT 25,26 .

Although the SEBT did not provide significant results, the Single Limb Hurdle Test, which involves lateral and medial jumps against obstacles, showed a significant improvement in functional performance with both rigid and the elastic tape, with no difference between them ${ }^{9}$. This result corroborates with the Figure-8-hop findings of the present study, because, like the Single Limb Hurdle Test, F8 involves jumps and displacements in a performance against time $e^{9,22}$.

According to Caffrey et al..22, F8 is an agility test that encompasses several physical components such as coordination and velocity and is, therefore, a good representative of the functional movements required during sports practice, mainly for generating joint multidirectional stress ${ }^{17}$. According to the same author ${ }^{22}$, tests involving only small rotational and lateral movements of the ankle that are not timed, such as SEBT, will hardly produce differences in performance. This fact may explain why there was significance with the use of implements in F8 performance and not in SEBT performance in the present study.

The study by Bicici, Karatas and Baltaci ${ }^{9}$ also found a significant worsening of functional performance in vertical jump during the use of rigid tape. According to the authors, the results are due to a smaller range of motion of dorsiflexion and plantiflexion caused by the restriction of the implement. In the present study, however, no performance decrease was observed with the use of rigid tape. Such result is probably due to the fact that many athletes evaluated had already used the material and were already familiarized to it, creating different compensation strategies for a best performance, especially in Figure-of-8 hop. In addition, according to Tregouét, Merland and Horodyski ${ }^{28}$, the tighter and more restrictive the tape application, the greater the chances of negatively affecting performance. Possibly, the force used during the application of the material was different in both studies.

Hettle et al. ${ }^{13}$ also evaluated the functional performance of athletes with chronic ankle instability through the SEBT, however, in only three directions (anterior, anterior-medial and posteromedial). The authors compared the performance of athletes without tape and with elastic tape and concluded that, in the same study, the implement did not significantly improve the functional performance of athletes. However, it was possible to see a positive tendency in relation to elastic tape in all directions, suggesting a slight increase of functionality. The results not in favour of the material, as in this study, may have occurred due to the time of action of the tapes. Hettle et al. ${ }^{13}$ mention that the elastic tapes begin their effect after 10 minutes of application. Moreover, in situations of chronic injury, better effects of the material may occur only after a longer time between application and sports practice. Unfortunately, there are still many divergences in the literature regarding the time of application and effect of this materia|9,13, which hampers the research methodology and the search for reliable results.

It is important to mention that, in the study of Bicici, Karatas and Baltaci ${ }^{9}$ as in that of Hettle et al. ${ }^{13}$, the application of elastic tape was performed with emphasis on the fibular stimulation, unlike this study that aimed to apply directly to the joint region. The literature supports new application methodologies 9 but has not found concrete results with the application methodologies used. In addition, considering that the results of this study were closer to the study by Hettle et al. ${ }^{13}$, this may have occurred because in both studies, the tape was applied with maximum tension, unlike Bicici, Karatas and Baltaci'.

Someeh et al.3 compared the functional performance of athletes with and without chronic ankle instability in two situations: without tape and with rigid tape. Figure-of-8 hop was performed in addition to two other tests also involving jumps and displacements against time. The authors verified that 
individuals with CAl had a significantly worse performance in all functional tests, and that there was a significant improvement of this performance when they used rigid tape, corroborating with the results of this study.

Halim-Kertanegara et al also performed studies with rigid tape using Figure-of-8 hop and SEBT. The sample consisted of active individuals, but not necessarily athletes, who performed the tests in two situations: without tape and with rigid tape. The authors verified that there was no improvement or significant performance loss in any of the tests, corroborating with this study in the case of SEBT and diverging for the F8 case. The results may have been different due to the tape application methodology. The present study, as well as the study by Someeh et al. ${ }^{3}$, tried to apply tapes for repositioning, whereas the study by Halim-Kertanegara et al." carried out an application that, apparently, had greater function of mechanical containment. In addition, the study by Halim-Kertanegara et al. ${ }^{*}$ used a cut-off point of the CAIT higher than the present study. However, these authors showed an important result: the use of ankle protection increased the perception of confidence, stability and safety of individuals in more dynamic tests, such as F8. Similar results were seen in the study by Delahunt et al. ${ }^{29}$, both in the effectiveness of the tapes and in the perception of the subject, which indicates that, even though ankle protection does not improve performance in some activity, it can lead to injured athletes returning to the sport earlier because they have more confidence* .

Considering the comfort of the tapes, few studies ${ }^{24,30}$ verified the difference between the rigid and elastic kind, but both agreed with the results of the present study, showing that the elastic tape is significantly more comfortable than the rigid one. The methods of applying the tapes, especially of rigid one, were very similar between studies; however in the study by Abián-Vicén et al. ${ }^{30}$ the authors found that both elastic and rigid tapes significantly restricted plantar flexion and inversion movements immediately after application. In the study by Kuni et al. ${ }^{24}$, elastic tape was effective only for stabilization of plantar and dorsal flexion, while rigid tape was effective for the stabilization of all ankle joint movements.

\section{CONCLUSION}

According to this study, the use of both rigid and elastic tape significantly improves the dynamic balance and, consequently, the functional performance of basketball athletes with CAl, only in situations of great joint stress, such as in Figure-of-8 hop test. Elastic tape seems to be an equally effective alternative to the rigid kind in these situations, in addition to being significantly more comfortable. However, it is suggested that more studies comparing the use of these types of tapes are performed in order to obtain greater clarity on the stabilizing capacity of the materials in the joint of chronically unstable ankles. Furthermore, the use of these materials seems to be well recommended because it increases the confidence and the stability perception of the athletes who use it, facilitating the return to sports practice after the occurrence of injuries.

All authors declare no potential conflict of interest related to this article.

AUTHORS' CONTRIBUTIONS: Each author made significant individual contributions to this manuscript. LCG (0000-0003-4166-9176)* and AMP (0000-0001-9781-1413)* were the main contributors in the drafting of the manuscript. LCG (0000-0003-4166-9176)*, LXL (0000-0002-5529-6131)*, HHS (0000-0001-8541-0866)*, GPF (0000-0002-3221-7680)* and RFLC (0000-0002-9913-2163)* contributed to the collection of data with the athletes. LCG (0000-0003-4166-9176)*, AMP (0000-0001-9781-1413)* and RFLC (0000-0002-9913-2163)* contributed to the intellectual conception of the study and discussed the results and final review of the manuscript. AMP (0000-0001-9781-1413)* and RFLC (0000-0002-9913-2163)* reviewed the article for publication. All authors contributed to the intellectual concept of the study. ${ }^{*} \mathrm{ORCID}$ (Open Researcher and Contributor ID).

\section{REFERENCES}

1. Thelen MD, Dauber JA, Stoneman PD. The clinical efficacy of kinesio tape for shoulder pain: a randomized, doubleblinded, clinical trial. J Orthop Sports Phys Ther. 2008;38(7):389-9.

2. Wilkerson GB. Biomechanical and neuromuscular effects of ankle taping and bracing. J Athl Training 2002;37(4):436-45.

3. Someeh M,Norasteh AA,Daneshmandi H, ASADI A. Influence of mulligan ankle taping on functional performance tests in healthy athletes and athletes with chronic ankle instability. Int J AthITher Train. 2015;20(1):39-45

4. Williams $S$, Whatman C, Hume PA, Sheerin K. Kinesio taping in treatment and prevention of sports injuries: a meta-analysis of the evidence for its effectiveness. Sports Med. 2012;42(2):153-64.

5. Halseth T, Mcchesney JW, Debeliso M, Vaughn R, Lien J. The effects of kinesiotaping on proprioception at the ankle. J Sports Sci Med. 2004;3(1):1-7.

6. Tremblay F, Karam S. Kinesio-taping application and corticospinal excitability at the ankle joint. J Athl Train. 2015;50(8):840-46.

7. Dizon JMR, Reyes JJB. A systemic review on the effectiveness of external ankle supports in the prevention of inversion ankle sprains among elite and recreational players. J SciMed Sport. 2010;13(3):309-17.

8. Briem K, Eythörsdötttir H, Magnúsdóttir RG, Pálmarsson R, Rúnarsdöttir T,Sveinsson T. Effects of kinesio tape compared with nonelastic sports tape and the untaped ankle during a sudden inversion perturbation in male athletes. J Orthop Sports PhysTher. 2011;41(5):328-35.

9. Bicici S, Karatas N, Baltaci G. Effect of athletic taping and kinesiotaping on measurements of functional performance in basketball players with chronic inversion ankle sprains. Int J Sports Phys Ther.2012;7(2):154-66

10. Peres MM, Cecchini L, Pacheco I, Pacheco AM. Efeitos do treinamento proprioceptivo na estabilidade do tornozelo em atletas de voleibol. RevBrasMed Esporte. 2014;20(2):146-50.

11. Hertel J. Functional anatomy, pathomechanics, and pathophysiology of lateral ankle instability. J Athl Train. 2002;37(4):364-75.

12. Gribble PA, Delahunt E, Bleakley C, Caulfield B, Docherty CL, Fourchet F, et al. Selection criteria for patients with chronic ankle instability in controlled research: a position statement of the International Ankle Consortium. J Orthop Sports Phys Ther. 2013;43(8):585-91.

13. Hettle $D$, Linton L, Baker JS, Donoghue O. The effect of kinesiotaping on functional performance in chronic ankle instability - preliminary study. Cli Res Foot Ankle. 2013;1(1):1-5.

14. Günay S, Karaduman A, Öztürk BB. Effects of aircast brace and elastic bandage on physical performance of athletes after ankle injuries.Acta OrthopTraumatol Turc. 2014;48(1):10-16.

15. Santos GR, Abbud EL, Abreu AJ. Determination of the size of samples: an introduction for new researchers. Rev Cient Symposium 2007;5:59-65.
16. Suda EY, Souza RN. Análise da performance funcional em indivíduos com instabilidade do tornozelo: uma revisão sistemática da literatura. Rev Bras Med Esporte 2009;15(3):233-37.

17. Docherty CL, Arnold BL, Gansneder BM, Hurwitz S, Gieck J. Functional-performance deficits in volunteers with functional ankle instability. J Athl Train. 2005;40(1):30-34.

18. Souza RF. O que é um estudo clínico randomizado? Revista da Faculdade de Medicina de Ribeirão Preto e do Hospital das Clínicas de FMRP. 2009;42(1):3-8

19. Noronha M, Refshauge KM, Kilbreath SL. Cross-cultural adaptation for the brazilian-portuguese version of the cumberlandankle instability tool (cait). Disabilrehabil. 2008;30(26):1-7.

20. Hertel J, Braham RA, Hale SA, Olmsted-kramer LC. Simplifying the star excursion balance test: analyse of subjetcts with and without chronic ankle instability.J Orthop Sports PhysTher. 2006;36(3):131-37.

21. Olmsted LC, Carcia CR, Hertel J, Schultz SJ. Efficacy of the star excursion balance tests in detecting reach deficits in subjects with chronic ankle instability. J Ath|Train. 2002;37(4):501-6.

22. Caffrey E, Docherty CL, Schrader J, Klossner J. The ability of 4 single-limb hopping tests to detect functional performance deficits in individuals. J Orthop Sports Phys Ther. 2009;39(11):799-806.

23. Schechter NL, Altman A, Weisman S. Report of the consensus conference on the management of pain in childhood câncer. Pediatrics. 1990;86(5):818-34

24. Kuni B,Mussler J,Kalkum E, Schmitt H, Wolf SI. Effect of kinesiotaping, non-elastic taping and bracing onsegmental foot kinematics during drop landing in healthysubjects and subjects with chroni ankle instability. Physiotherapy 2016;102(3):287-93.

25. Silva PB, Gonçalves M. Suportes de pé e tornozelo: efeitos na biomecânica e na prevenção de lesões Motriz 2007;13(4):312-23.

26. Hardy L, Huxel K, Brucker J, Nesser T. Prophylatic ankle braces and star excursion balance measures in healthy volunteers. J Athl Train. 2008;43(4):347-51.

27. Ambegaonkar JP, Redmond CJ, Winter C, Ambegaonkar SJ, Thompson B, Guyer S. Ankle stabilizers affect agility but not vertical jump or dynamic balance performance. Foot Ankle Spec. 2011;4(6):354-60

28. Trégouet $P$, Merland F, Horodyski MB. A comparison of the effects of ankle taping styles on biomechanics during ankle inversion. AnnPhysRehabil Med. 2013;56(2):113-22.

29. Delahunt E, Mcgrath A, Doran N, Coughlan GF.Effect of taping on actual and perceived dynamic postural stability in persons with chronic ankle instability. Arch Phys Med Rehabil. 2010;91(9):1383-89.

30. Abián-Vicén J, Alegre LM, Fernández-Rodríguez JM, Aguado X. Prophylaticankletaping: elastic versus inelastictaping.Foot Ankle Int. 2009;30(3):218-25. 